\title{
MORBIDITY AND MORTALITY DUE TO AIDS: A STUDY OF BURDEN OF DISEASE AT A MUNICIPAL LEVEL
}

Jane DA SILVA(1,2), Victoria RAMOS(2), Helena Caetano Gonçalves DA SILVA(1) \& Jefferson TRAEBERT(1,2)

\begin{abstract}
SUMMARY
Introduction: The purpose of measuring the burden of disease involves aggregating morbidity and mortality components into a single indicator, the disability-adjusted life year (DALY), to measure how much and how people live and suffer the impact of a disease. Objective: To estimate the global burden of disease due to AIDS in a municipality of southern Brazil. Methods: An ecological study was conducted in 2009 to examine the incidence and AIDS-related deaths among the population residing in the city of Tubarao, Santa Catarina State, Brazil. Data from the Mortality Information System in the National Health System was used to calculate the years of life lost (YLL) due to premature mortality. The calculation was based on the difference between a standardized life expectancy and age at death, with a discount rate of 3\% per year. Data from the Information System for Notifiable Diseases were used to calculate the years lived with disability (YLD). The DALY was estimated by the sum of YLL and YLD. Indicator rates were estimated per 100,000 inhabitants, distributed by age and gender. Results: A total of 131 records were examined, and a 572.5 DALYs were estimated, which generated a rate of 593.1 DALYs/100,000 inhabitants. The rate among men amounted to 780.7 DALYs/100,000, whereas among women the rate was 417.1 DALYs/100,000. The most affected age groups were 30-44 years for men and 60-69 years for women. Conclusion: The burden of disease due to AIDS in the city of Tubarao was relatively high when considering the global trend. The mortality component accounted for more than $90 \%$ of the burden of disease.
\end{abstract}

KEYWORDS: Morbidity; Mortality; AIDS; Burden of disease.

\section{INTRODUCTION}

With the advent of the antiretroviral therapy, there was a reduction in mortality and morbidity caused by HIV/AIDS, and the disease has become a chronic condition ${ }^{17}$. However, it remains a significant public health problem on a global scale ${ }^{1}$ and its mortality rates are still used to identify it as such ${ }^{10}$. Despite its importance, mortality rates seem limited because such an indicator does not infer the reduction in quality of life caused by HIV/AIDS. Therefore, it has been considered inappropriate for measuring the health of a population ${ }^{9}$.

In recent decades, the burden of disease has been investigated, which is nothing more than aggregating, in a single indicator, the data on mortality and morbidity generated by a disease or health condition. This health indicator is termed disability-adjusted life years (DALY) ${ }^{12}$. One DALY represents one year of healthy life that is lost or lived with disability. This is an indicator that seeks to measure simultaneously the impact of mortality and health problems affecting the quality of life of individuals. It is defined as the sum of the number of years of life lost (YLL) prematurely, and the number of years lived with disability (YLD). Based on this premise, the burden of disease calculation has shown to be a more comprehensive indicator for measuring the burden that HIV/AIDS contributes to society, thus providing a better basis to guide fundamental improvements in the health system.

The Santa Catarina State reported 2,298 cases of HIV among adults in 2011. The incidence rate in 2011 was 36.4 cases per 100,000 inhabitants of both sexes, and the city of Tubarao ranked $35^{\text {th }}$ nationally in the number of AIDS cases and $13^{\text {th }}$ in the Santa Catarina State, with an incidence rate of 40.1/100,000 inhabitants ${ }^{3}$. A study on the epidemiological profile of patients with HIV treated in this municipality in 2010 revealed that the average age was nearly 40 years and there was predominance of men (57\%), and in accordance with the criteria for the disease notification, $45.2 \%$ of these patients had AIDS. In addition, $50 \%$ had detectable viral loads and $64 \%$ were on antiretroviral therapy. In that study, the incidence rate was higher among Caucasians than among other racial and ethnic groups, and also higher among those with less education. Sexual contact was the main mode of transmission ${ }^{15}$. Literature data on burden of disease caused by AIDS is scarce in Brazil. To date, the burden of AIDS in the Brazilian municipalities is unknown. The aim of this study was to estimate the burden of disease due to AIDS at a municipal level, namely in Tubarao, Santa Catarina State, Brazil. The city of Tubarao is

(1) Universidade do Sul de Santa Catarina (UNISUL), Programa de Pós-graduação em Ciências da Saúde, Florianópolis, Santa Catarina, Brasil.

(2) Universidade do Sul de Santa Catarina (UNISUL), Departamento de Medicina, Florianópolis, Santa Catarina, Brasil.

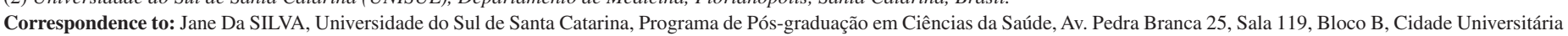
Pedra Branca, 88137-270 Palhoça, SC, Brasil. Phone: 5548 3279-1167 or 3279-1168. E-mail: janedasilva1808@ gmail.com 
DA SILVA, J.; RAMOS, V.; DA SILVA, H.C.G. \& TRAEBERT, J. - Morbidity and mortality due to AIDS: a study of burden of disease at a municipal level. Rev. Inst. Med. Trop. Sao Paulo, 57(5): 407-11, 2015.

located in the southern region of the Santa Catarina State, $133 \mathrm{~km}$ from the State capital. The estimated population was 96,529 inhabitants in 2009. Santa Catarina is famous for its ceramics and tourism, centering on thermal spas 5 .

\section{METHODS}

In 2009, an observational epidemiological study with an ecological design was conducted on data and notifications of deaths from AIDS. Inclusion criteria were deaths and reported AIDS cases of individuals, both children and adults, living in the municipality of Tubarao, Santa Catarina State, in that year. The year of 2009 was chosen because, at the time of the data collection, it was the latest year for which there were available consolidated data on the Mortality Information System (SIM).

The survey followed the method for burden of disease study, carried out for Brazil as a whole ${ }^{6}$. The Mortality Information System (SIM), available at www.datasus.gov.br (retrieved on November $15^{\text {th }}, 2012$ ) was used to collect data on the number of AIDS-related deaths in 2009. AIDS-related deaths (ICD 10: B20 to B24) were included as the primary or secondary cause. The Information System for Notifiable Disease (SINAN) was used to collect data of morbidity of individuals confirmed as AIDS cases in 2009. Operations were double-checked to avoid possible duplication of cases. Thus, each case was counted only once. Deaths from AIDS were reported to the SIM, whereas AIDS cases were notified to the SINAN. Similarly to the Study of Global Burden of Disease in Brazil, an addition of $50 \%$ incident cases was made to compensate for possible underreporting ${ }^{6}$.

Calculation of the mortality indicator - YLL: The YLL was calculated as the difference between age at death and the parameters used in the study of burden of disease in Brazil, i.e. life expectancy at birth, as in Japan, which is 80 years for men and 82.5 years for women. The use of a standardized life expectancy rate allows for international comparability. A discount rate of $3 \%$ was applied to years of life lost in the future ${ }^{6}$. Thus, future years suffered from the effect of the discount rate so that each year of healthy life lost was recorded as $97 \%$ of the previous year, and so on.

Morbidity indicator calculation - YLD: The number of years lived with disability (YLD) was estimated by multiplying the weight of the disability and its duration, using incident cases. In studies of burden of disease, the value of time lived with a non-fatal health situation or disability is called "disability weights"12. The weight of disability (0.167) recommended by the World Health Organization for AIDS ${ }^{18}$ was used. The weight used was that one given to cases under treatment. All cases were regarded as "under treatment". The mean disease duration was set at 108 months $^{8}$.

Disease burden calculation - DALY: A DALY is equal to the sum of YLL and YLD. The number of years of life lost (YLL), YLD and DALY rates were calculated per 100,000 inhabitants, for each age group/gender strata. For that purpose, information about residents in the municipality in 2009 was collected, estimated by gender and age group, according to the Brazilian Geography and Statistics Institute - IBGE's preliminary population total estimates for intercensus years available at www.datasus. gov.br (retrieved on November $15^{\text {th }}, 2012$ ). Given that age information was disaggregated, the subjects were classified into nine age groups, according to the methodology used by the burden of disease study in
Brazil $^{6}$, i.e. $<1$ year, 1-4 years, 5-14 years, 15-29 years, 30-44 years, 45-59 years, 60-69 years, 70-79 years, and 80 years or older.

Ethical implications: This study used data from official health data systems available in the public domain, with no ethical breaches.

\section{RESULTS}

A total of 131 records regarding AIDS were analyzed in the municipality of Tubarao in 2009, of which $21(16 \%)$ were deaths and $110(84 \%)$ reported cases.

Among the surveyed subjects, 468.8 YLLs were estimated, which generated a rate of 485.6 YLLs/100,000 inhabitants. The YLL found for males was 304.7, which generated 652.1 YLLs/100,000 men, whereas for females, the YLL found was 164.1, which generated a rate of 329.5 YLLs /100,000 women. The mean age at notification was 38.8 years (SD $=9.2)$, and the mean age at death was 43.0 years $(\mathrm{SD}=12.4)$.

Among males, the age group of 30-44 years was the most affected, with 1,393.6 YLLs/100,000 men at that age group, followed by the age group of 45-59 years, with 887.3 YLLs/100,000 men at that age group. Among females, the age group of 60-69 years was the most affected, with 1,292.46 YLLs/100,000 women at that age group, followed by the age group of 45-59 years, with 635.35 YLLs/100,000 women at that age group, as shown in Figure 1.

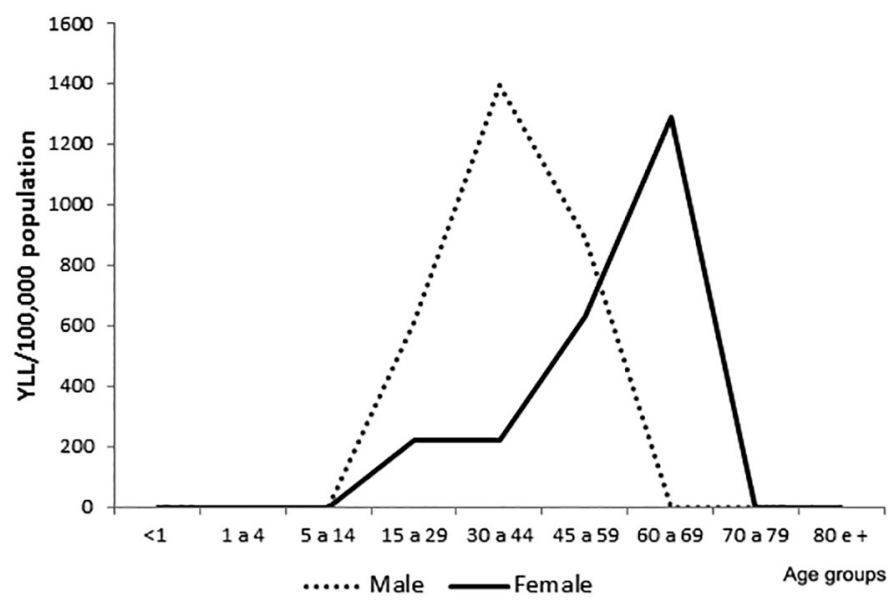

Fig. 1 - Distribution of years of life lost (YLL) rates per 100,000 inhabitants according to age and gender. Tubarão, Santa Catarina State, 2009.

In total, 103.7 YLDs were estimated, which generated a rate of 107.4 YLDs/100,000 inhabitants. Among males, the number of YLDs was 60.1, which generated a rate of 128.7 YLDs/100,000 men, whereas among females, it was 43.6 YLDs, generating a rate of 87.5 YLDs/100,000 women.

Among males, the age group of 30-44 years was the most affected, followed by the age group of 45-59 years, with 316.6 and 201.1 YLDs/100,000 men at those age groups, respectively.

Among females, the age group of 30-44 years was the most affected, followed by the age group of 45-59 years, with 242.6 and 75.9YLDs/100,000 
women at those age groups, respectively, as shown in Figure 2.

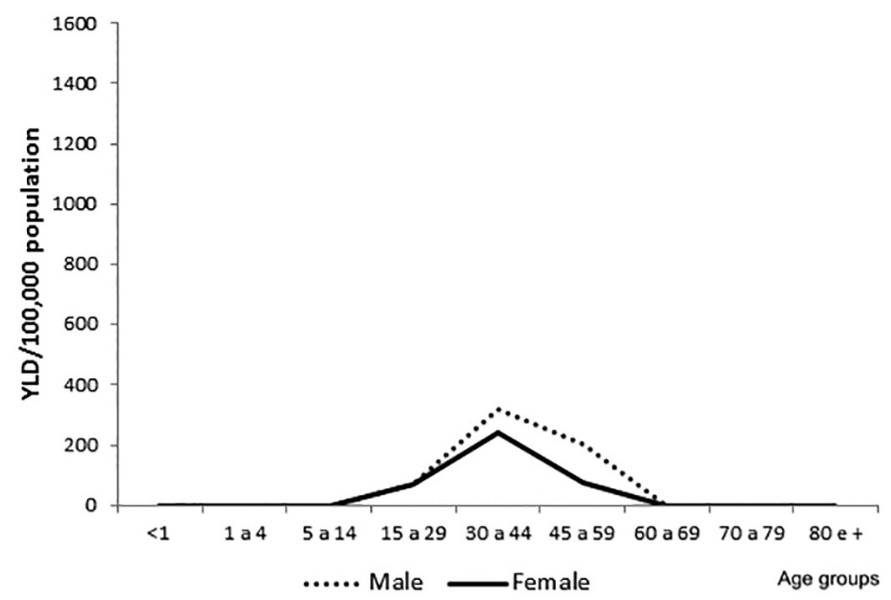

Fig. 2 - Distribution of years lived with disability (YLD) rates per 100,000 inhabitants according to age and gender. Tubarão, Santa Catarina State, 2009.

In total, 572.5 DALYs were estimated, which generated a rate of 593.1 DALYs/100,000 inhabitants. Among males, the number of DALYs was 364.8, which generated a rate of 780.7 DALYs/100,000 men, whereas among females it was 207.7 DALYs, which generated a rate of 417.1 DALYs/100,000 women.

Given that the DALY is the sum of YLL and YLD, we observed again that, among males, the age group of 30-44 years was the most affected, with 1,712.9 DALYs/100,000 men at that age group, followed by the age group of 45-59 years, with 1,088.4 DALYs/100,000 men at that age group. Among females, the age group of 60-69 years was the most affected, with 1,292.5 DALYs/100,000 women at that age group, followed by the age group of 45-59 years, with 711.2 DALYs per 100,000 women at that age group, as illustrated in Figure 3.

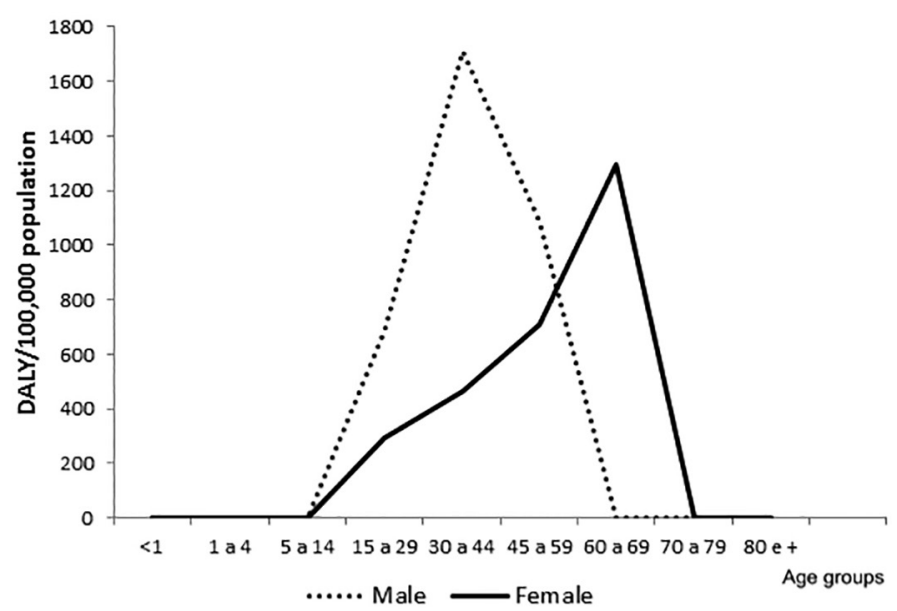

Fig. 3 - Distribution of disability-adjusted life years (DALY) rates per 100,000 inhabitants according to age and gender. Tubarão, Santa Catarina State, 2009. DALY/100,000 population

\section{DISCUSSION}

This study showed that there were 21 AIDS-related deaths and 110 notifications of AIDS cases in the municipality of Tubarao in 2009. The year 2009 was marked in Santa Catarina by a peak of AIDS-related mortality rate with 615 deaths and a mortality rate of 10.0/100,000 inhabitants. Men had double the mortality rate compared to women, and Tubarao was among the 11 municipalities in the State with the highest mortality rates ${ }^{16}$. Possible causes for this increased mortality include early diagnosis failures, lack of adherence to treatment, antiretroviral treatment regimens, inadequate prophylaxis, difficult access to medical care, and characteristics of opportunistic diseases in the Santa Catarina State ${ }^{13}$.

The burden of AIDS in Tubarao generated rates of 485.6 YLLs/100,000 inhabitants, 107.4 YLDs/100,000 inhabitants, and consequently, 593.1 DALYs/100,000 inhabitants. In addition to the obvious relevance of this information at the local, State and national levels, these results allow the comparison of data between countries because the study has used internationally consolidated methods for burden of disease studies.

The burden of disease indicators are appropriate for health planning at a municipal level because they allow researchers to make comparisons, they provide valuable information for public health policymakers, based not only on mortality rates but also on the impact generated by the nonfatal cases. These parameters enable direct interventions to improve the quality of health care for specific groups, such as individuals living with HIV.

As soon as the importance of using close-to-reality data for planning health actions at a municipal level is understood, it will be possible to move on to the analysis of the behavior of the used indicator. It was found that both, the YLL and YLD rates, were much higher among men than women, resulting in higher levels of burden of AIDS in men. This finding is consistent with those found in other countries ${ }^{1,8}$. Moreover, data from the Brazilian literature, although not so recent, indicated that the level of AIDS burden was higher among men than women ${ }^{6}$. Similarly, in 2009, data from the Santa Catarina State also indicated that the level of AIDS burden was higher among men than women ${ }^{7}$. However, due to the progressive reduction in the disease male/female incidence ratio over the last few years, it has been stated that AIDS is undergoing a feminization process $^{4}$. In Tubarao, an epidemiological study conducted in 2010 showed that the infection was predominant among men $(57 \%)^{15}$. Therefore, regional and State gender-related differences must be taken into account.

The analysis of the burden components revealed that the YLL indicator, which reflects mortality, accounted for $81.9 \%$ of DALYs. As it can be seen, AIDS-related mortality still poses a high burden to the local community. Indeed, the years lost due to premature death are quite high for the general population. Some studies show that YLL is $77.5 \%$ in Santa Catarina ${ }^{7}$, and $75.2 \%$ in the world ${ }^{9}$. Mortality rates have reduced in Brazil, especially after the introduction of the universal free distribution of antiretroviral drugs. However, mortality remains high, and Santa Catarina is one of the Brazilian States with the highest rates ${ }^{14}$. This finding shows how AIDS generates early mortality at a municipal level. These data are relevant not only for the clear perception of its high dimension within the Santa Catarina State, and the country, but mainly help to boost the generation of effective control policies and preventive education programs.

Economic, social and cultural inequalities are everywhere in 
the world. They are factors that directly interfere with the specific vulnerability of these populations to HIV/AIDS infection. A study by SCHUELTER-TREVISOL et al. showed that AIDS prevalence was higher among poor educated individuals in Tubarao in $2010^{15}$. In this context, the education level is closely linked to vulnerability issues, given that it affects the degree of information. Besides education, unsafe sex and drug use must be considered, because these are frequent forms of HIV transmission in Tubarao ${ }^{15}$. Accordingly, a study that assessed adherence to antiretroviral therapy in Tubarao showed that the diagnosis of opportunistic diseases is one of the factors associated with adherence to treatment ${ }^{2}$. A higher adherence to treatment in advanced stages of the disease is accompanied by a high risk of mortality and may represent a greater burden of disease because of the late onset of treatment.

Years lived with disability, represented by the YLD component that determines indirectly the loss of quality of life, although having the lowest rate in the burden of disease cannot be overlooked. This is particularly important because the age group of 30-44 years was the most affected both in men and women, when people are living the most productive years of their lives. Living with AIDS disabilities in this stage of life can lead to losses in the medium and long run considering both, the individual and the society. Review strategies for prevention and searching to adapt conditions of people in that situation, mainly targeting the younger age groups, may lead to better adaptability and improve quality of life.

Although this study was restricted to a particular municipality, it used a method that has been stimulated in epidemiological research worldwide. This is particularly relevant because it allows for multiple comparisons, both globally and between communities. While serving as the basis for future longitudinal analyses, it constitutes a unique opportunity given that the studies on burden of disease reflect a summary of the population's health $^{11}$, with special importance in the case of AIDS.

One limitation of this type of study is the fact that there is the possibility of underreporting of AIDS cases and deaths. Moreover, given that this is an ecological study, the interpretation of results should be limited to the group level, avoiding the extrapolation to the individual level.

In conclusion, studies on AIDS-related burden at a municipal level can be an important tool for health planning. In the municipality of Tubarao, the burden of AIDS was high when considering the global trend. The YLL mortality component accounted for more than $90 \%$ of the indicator, which should be considered carefully, because of the burden that it represents for the community. With regard to the YLD disability component, although it has indicated a lower burden than YLL, it should be taken into account in planning public health policies, given that the most affected age group was also the most productive one.

\section{RESUMO}

\section{Morbidade e mortalidade por AIDS: estudo sobre o impacto da doença em nível municipal}

Introdução: A proposta de mensuração do impacto da doença implica a integração em um mesmo indicador, o DALY, de componentes de morbidade e mortalidade, para medir quanto e como as populações vivem e sofrem o impacto de determinada doença. Objetivo: Estimar o impacto da doença causada pela Aids em um município do sul do
Brasil. Métodos: Foi desenvolvido um estudo ecológico envolvendo registros de incidência e de óbitos por Aids na população residente em Tubarão, SC, em 2009. Para cálculo do componente de mortalidade-YLL foram utilizados dados de mortalidade do Sistema de Informações de Mortalidade do Sistema Único de Saúde. Calculou-se pela diferença de uma expectativa de vida padronizada e a idade do óbito, aplicada uma taxa de desconto de $3 \%$ ao ano. Para cálculo do componente de morbidadeYLD foram utilizados dados do Sistema de Informação de Agravos de Notificação. O DALY foi estimado pela soma do YLL e YLD. Foram estimadas as taxas dos indicadores por 100 mil habitantes segundo sexo e faixa etária. Resultados: Foram analisados 131 registros e estimados 572,5 DALYs, o que gerou uma taxa de 593,1 DALYs/100 mil habitantes. No sexo masculino a taxa foi de 780,7 DALY/100 mil homens, já nas mulheres esta taxa correspondeu a 417,1 DALYs/100 mil mulheres. As faixas etárias mais acometidas foram de 30 a 44 anos no sexo masculino e de 60 a 69 anos no sexo feminino. Conclusão: O impacto da doença causada pela Aids no município de Tubarão mostrou-se elevado quando considerada a tendência global. O componente de mortalidade contribuiu com mais de $90 \%$ do indicador de impacto da doença.

\section{ACKNOWLEDGEMENTS}

This study was partially subsidized by the Unisul Research Support Program (PUIP), University of Southern Santa Catarina, to which the authors express their gratitude.

\section{REFERENCES}

1. Bermudez-Tamayo C, Martin JJM, Ruiz-Pérez I, Lima AOL. Factors associated with improvement in disability-adjusted life years in patients with HIV/AIDS. BMC Public Health. 2008;8:362.

2. Blatt CR, Citadin CB, Souza FG, Mello RG, Galato D. Avaliação da adesão aos antiretrovirais em um município no sul do Brasil. Rev Soc Bras Med Trop. 2009;42:131-6.

3. Brasil. Ministério da Saúde. Boletim epidemiológico HIV-AIDS: $52^{\text {a }}$ semana epidemiológica; ano I, n1, dezembro de 2012. Brasília: Ministério da Saúde; 2012. [cited 2014 Aug 9]. Available from: <http://www.aids.gov.br/sites/default/files/anexos/ publicacao/2012/52654/boletim_2012_final_pdf_14028.pdf>

4. Brasil. Ministério da Saúde. Plano integrado de enfrentamento da feminilização da epidemia de AIDS e outras DST. Brasília: Ministério da Saúde; 2007. [cited 2013 Dec 5]. Available from: <http://bvsms.saude.gov.br/bvs/publicacoes/plano_feminizacao_ final.pdf>

5. Brasil. Secretaria de Apoio às Micro e Pequenas Empresas de Santa Catarina. Santa Catarina em números: Tubarão/Sebrae/SC. Florianópolis: Sebrae/SC; 2013. [cited 2014 Aug 10]. Available from: <https://atendimento.sebrae-sc.com.br/projetos/ portal_sebrae-sc/uploads/pdfs-municipios/relatorio-municipal-tubarao.pdf>

6. Fundação Oswaldo Cruz. Escola Nacional de Saúde Pública. Estimativa de doença no Brasil. Rio de Janeiro: FIOCRUZ; 2002. [cited 2013 Sep 14]. Available from: <http:// www.scribd.com/doc/23050704/Projeto-Carga-de-Doença-Fiocruz>

7. Gonçalves e Silva HC, Silva J, Traebert J. Burden of AIDS in a Brazilian State. J Infect Public Health. 2014;7:308-13.

8. Guibu IA, Barros MBA, Donalísio MR, Tayra A, Alves MCGP. Survival of AIDS patients in the Southeast and South of Brazil: analysis of the 1998-1999 cohort. Cad Saude Publica. 2011;27(Suppl 1):s79-92.

9. McKenna MT, Michaud CM, Murray CJL, Marks JS. Assessing the burden of disease in the United States using disability-adjusted life years. Am J Prev Med. 2005;28:41523. 

57(5): 407-11, 2015.

10. Melse JM, Essink-Bot ML, Kramers PG, Hoeymans N. A national burden of disease calculation: Dutch disability-adjusted life years. Dutch Burden of Disease Group. Am J Public Health. 2000;90:1241-7.

11. Murray CJ, Vos T, Lozano R, Naghavi M, Flaxman AD, Michaud C, et al. Disabilityadjusted life years (DALYs) for 291 diseases and injuries in 21 regions, 19902010: a systematic analysis for the global burden of disease study 2010. Lancet. 2012;380(9859):2197-223

12. Murray CJ. Quantifying the burden of disease: the technical basis for disability-adjusted life years. Bull World Health Organ. 1994;72:429-45.

13. Oliveira OV. Situação epidemiológica da Aids em Santa Catarina. Florianópolis: Boletim Epidemiológico DST/AIDS; 2001. [cited 2014 Aug 11]. Available from: <http://www. saude.sc.gov.br/inf_saude/not_comp/aids/Boletim.pdf>

14. Reis AC, Santos EM, Cruz MM. A mortalidade por Aids no Brasil: um estudo exploratório de sua evolução temporal. Epidemiol Serv Saúde. 2007;16:195-205
15. Schuelter-Trevisol F, Pucci P, Justino AZ, Pucci N, Silva ACB. Perfil epidemiológico dos pacientes com HIV no sul do Estado de Santa Catarina, Brasil, em 2010. Epidemiol Serv Saúde. 2013;22:87-94.

16. Silva IB, Gandin NI. O perfil epidemiológico da AIDS. Florianópolis: Secretaria de Estado da Saúde, Diretoria de Vigilância Epidemiológica. 2010. [cited 2014 Jun 28] Available from: <http://www.dive.sc.gov.br/conteudos/publicacoes/livros_artigos/ Perfil_Epidemiologico_AIDS_2010.pdf>

17. Torres TS, Cardoso WS, Velasque LS, Martins LMS, Oliveira MS, Veloso VG, et al. Aging with HIV: an overview of an urban cohort in Rio de Janeiro (Brazil) across decades of life. Braz J Infect Dis. 2013;3:324-31

18. World Health Organization. Global Burden of disease 2004 update: disability weights for disease and conditions. [cited 2013 Aug 18]. Available from: <http://www.who int/healthinfo/global_burden_disease/GBD2004_DisabilityWeights.pdf>

Received: 17 April 2014

Accepted: 5 January 2015 